\title{
Selection of effective macroalgal species and tracing nitrogen sources on the different part of Yantai coast, China indicated by macroalgal $\delta^{15} \mathrm{~N}$ values
}

\author{
Yujue Wang ${ }^{\mathrm{a}}$, Dongyan Liu ${ }^{\mathrm{a}, *}$, Pierre Richard ${ }^{\mathrm{b}}$, Baoping $\mathrm{Di}^{\mathrm{a}}$ \\ a Key Laboratory of Coastal Environmental Processes and Ecological Remediation, Yantai Institute of Coastal Zone Research, Chinese Academy of Sciences, Yantai, Shandong 264003, PR China \\ b Littoral, Environnement et Sociétés, UMR 7266 CNRS-Université de La Rochelle, 2 rue Olympe de Gouges, 17000 La Rochelle, France
}

\section{H I G H L I G H T S}

- Yantai coast was affected by three types of DIN sources.

- Macroalgal species suitable or not for DIN source tracing were suggested;

- TN and $\delta^{15} \mathrm{~N}$ were affected by nutrient concentrations and the metabolic factors.

- P instead of $\mathrm{N}$ limited the tissue $\mathrm{N}$ uptake in low nutrient concentration sites.

\section{A R T I C L E I N F O}

\section{Article history:}

Received 17 July 2015

Received in revised form 16 September 2015

Accepted 9 October 2015

Available online $\mathrm{xxx}$

Editor: D. Barcelo

\section{Keywords:}

DIN sources

Macroalgae

$\delta^{15} \mathrm{~N}$

Indicator

Yantai coast

\section{G R A P H I C A L A B S T R A C T}

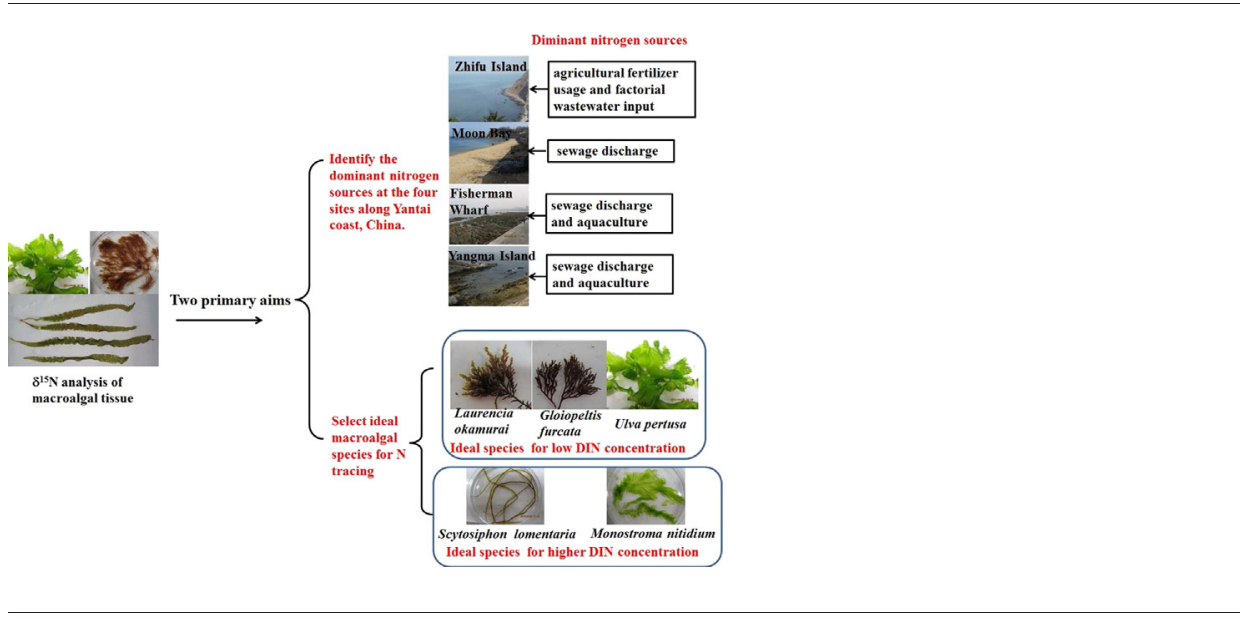

A B S T R A C T

To determine the dominant nitrogen sources and select effective macroalgal species for monitoring eutrophication along the Yantai coast, the total carbon (TOC), total nitrogen (TN) and nitrogen stable isotope ratio $\left(\delta^{15} \mathrm{~N}\right)$ in macroalgal tissue were analyzed in conjunction with environmental variables in seawater along the Yantai coastline. The ranges of macroalgal tissue $\delta^{15} \mathrm{~N}$ values together with dissolved inorganic nitrogen (DIN) composition indicated that except for the atmospheric deposition, there were three dominant types of nitrogen sources along the Yantai coast, with the agricultural fertilizer usage and factorial wastewater input at the S1 (Zhifu Island coast), the sewage discharge at S2 (the Moon Bay coast), the sewage discharge together with aquaculture impacts at S3 (Fisherman Wharf coast) and S4 (the Horse Island coast). Macroalgal growth were not limited by DIN but limited by P at S2, S3 and S4. Macroalgal species suitable or not for DIN source tracing along the Yantai coast were discussed. For sites with low DIN concentration, many species of three phyla could be used for DIN sources tracing with Laurencia okamurai, Gloiopeltis furcata and Ulva pertusa being ideal species. For site with high DIN concentration, however, species of Rhodophyta were not suitable and only Scytosiphon lomentaria and Monostroma nitidium were chosen.

(c) 2015 Elsevier B.V. All rights reserved.

\footnotetext{
* Corresponding author at: Yantai Institute of Coastal Zone Research, CAS, 17th Chunhui Road, Laishan District, Yantai 264003, China.

E-mail address: dyliu@yic.ac.cn (D. Liu).
} 


\section{Introduction}

Over the last several decades, anthropogenic activities (e.g., fertilizer use, sewage discharge, aquaculture) have dramatically increased the nitrogen loadings along coastlines and greatly accelerated the deterioration of marine ecosystems (Nixon, 1995; Bricker et al., 2008; Howarth et al., 2011). Distinguishing nitrogen sources is not only necessary to understand the biogeochemical cycle in coasts and estuaries but also important to establish effective coastal environmental management policies (Rogers, 2003; Kamer et al., 2004). Nitrogen stable isotope ratio $\left(\delta^{15} \mathrm{~N}\right)$ has been successfully applied to trace nitrogen sources over the last decade, depending on their specific signatures (McClelland and Valiela, 1998; Savage and Elmgren, 2004; Ochoa-Izaguirre and Soto-Jiménez, 2013; Viana and Bode, 2015). For example, sewage effluent or animal wastewaters are characterized by high values of $\delta^{15} \mathrm{~N}$, from 7\% to 50.1\%。 (Kendall, 1998; Savage and Elmgren, 2004; Dailer et al., 2010), while fertilizer derived from industrial fixation of $\mathrm{N}_{2}$ are depleted in $\delta^{15} \mathrm{~N}$ values, from $-7.5 \%$ 。 to $6.6 \%$ 。 (Heaton, 1986; Macko and Ostrom, 1994; Vitòria et al., 2004; Dailer et al., 2010). Particularly, the use of $\delta^{15} \mathrm{~N}$ of macroalgae and other autotrophic organisms to identify nitrogen sources in coastal ecosystems has become more popular in the last few years, e.g., Moreton Bay, Australia (Costanzo et al., 2001), Himmerfjärden Bay, Sweden (Savage and Elmgren, 2004), Baltic Sea (Deutsch and Voss, 2006; Schubert et al., 2013), Hanalei Bay, Kauai, USA (Derse et al., 2007), Narragansett Bay, RI, USA (Thornber et al., 2008), Gulf of California, USA (Piñón-Gimate et al., 2009; Ochoa-Izaguirre and Soto-Jiménez, 2013, 2015), Maui, Hawai'i, USA (Dailer et al., 2010), Ría de A Coruña, Northwestern Spain (Viana and Bode, 2013, 2015), and Marennes-Olèron Bay, France (Raimonet et al., 2013). The basic premise of nitrogen sources tracing with macroalgal tissue $\delta^{15} \mathrm{~N}$ is that it could reflect the nitrogen source in a predictable manner (Cohen and Fong, 2005).

However, $\delta^{15} \mathrm{~N}$ values in the macroalgal tissue may be modified by metabolic activity or environmental changes. Macroalgal internal structure, attachment strategies, growing rates, reproduction strategies, preference assimilation for nitrogen chemical, uptake kinetics, storage capacity and individual condition of species (e.g., juvenile or adult) could cause the difference of $\delta^{15} \mathrm{~N}$ values between macroalgal species (Ochoa-Izaguirre and Soto-Jiménez, 2015). For example, foliose and filamentous macroalgae such as Ulva intestinalis could more efficiently reflect the $\delta^{15} \mathrm{~N}$-DIN variations because their faster uptake and growth rates (Teichberg et al., 2008; Dailer et al., 2010; Ochoa-Izaguirre and Soto-Jiménez, 2015). Environmental factors such as seawater nutrient levels, temperature and light may also result in the difference of macroalgal $\delta^{15} \mathrm{~N}$ values (Umezawa et al., 2002; Derse et al., 2007; Dudley et al., 2010; Viana and Bode, 2015). Although the effect of environmental nitrogen status and concentration on macroalagal fractionation remains controversial (Cohen and Fong, 2004; Dailer et al., 2010; Dudley and Shima, 2010; Kaldy, 2011), significant fractionation was showed with high nitrogen concentration in the water column and high nitrogen content in macroalgae (Thornber et al., 2008; Kaldy, 2011; Viana and Bode, 2015). Fractionation during nitrogen uptake normally leads to depletion of $\delta^{15} \mathrm{~N}$ in the algal tissues compared to seawater nitrogen. However, no fractionation or even more enriched $\delta^{15} \mathrm{~N}$ in macroalgal tissues than nitrogen in the surrounding water was also found (Cohen and Fong, 2004, 2005; Piñón-Gimate et al., 2009; Viana and Bode, 2015). Thus, it still needs to be cautious to read the data of $\delta^{15} \mathrm{~N}$ in algal tissue. Effects from both internal metabolic factors together with the outside environmental impacts should be taken into account when we evaluate the nitrogen sources with macroalgal $\delta^{15} \mathrm{~N}$ analysis.

Most published studies of nitrogen sources with macroalgal $\delta^{15} \mathrm{~N}$ were focused in the mean isotopic signatures or based on the analysis of only one to three species (Tyler and McGlathery, 2006; Thornber et al., 2008; Kaldy, 2011; Carballeira et al., 2013, 2014; Viana and Bode, 2013, 2015). However, relatively few studies were focused on comparison of interspecific differences of isotope expression and selection of more effective macroalgal species as indicator (Dailer et al., 2010; Ochoa-Izaguirre and Soto-Jiménez, 2013, 2015). To get excellent indicators of nitrogen sources, more studies are needed to explain the effects of factors related to interspecific difference of macroalgal $\delta^{15} \mathrm{~N}$.

Yantai is a coastal city located in the northern Yellow Sea, China with a population of approximately one and a half million (Fig. 1). Over the last three decades, increased nitrogen loadings along the coastline, resulting from anthropogenic activities (e.g., agriculture, marine aquaculture, factorial, and sewage discharge), have distinctly degraded the health of the coastal ecosystem (Zhou et al., 2006; Wang et al., 2012). Frequent micro- and macroalgal blooms in coastal water have threatened the security of marine aquaculture and tourism (Hao et al., 2011; Liu et al., 2013; Han and Liu, 2014). Therefore, controlling nitrogen loading and establishing effective management policies are urgent matters.

In this study, we measured $\delta^{15} \mathrm{~N}$ values of macroalgal tissue on the Yantai coast with two primary aims: 1 ) to study the factors related to variation of nitrogen content and $\delta^{15} \mathrm{~N}$ values of macroalgal species and select the most effective indicator species for tracing nitrogen sources on the Yantai coast; 2) to identify the dominant nitrogen sources in different part of this area.

\section{Material and methods}

\subsection{Study area}

Yantai has an approximately $101 \mathrm{~km}$ long rocky shore (Fig. 1) with a regular semi-diurnal tide. It is a typical temperate region with surface sea temperatures of approximately 2 to $3{ }^{\circ} \mathrm{C}$ in winter and 24 to $28{ }^{\circ} \mathrm{C}$ in summer and surface sea salinities generally of 29.0 to 31.5 psu due to river input along the coastline (Zhuang and Chen, 2003). Abundant macroalgae are distributed in the littoral zone, including Rhodophyta (e.g., Ceramium, Gelidium), Chlorophyta (e.g., Ulva) and Phaeophyta (e.g., Colpomenia) (Zhuang et al., 2010; Han and Liu, 2014), which makes it possible to use the $\delta^{15} \mathrm{~N}$ values in macroalgal tissue to trace nitrogen sources along the coastline.

Four sites along the coastline were chosen for collecting algae and water samples (Fig. 1). Site 1 (S1: 37 $37^{\prime} 18.35^{\prime \prime}-37^{\circ} 37^{\prime} 20.42^{\prime \prime} \mathrm{N}$, $121^{\circ} 22^{\prime} 12.53^{\prime \prime}-121^{\circ} 22^{\prime} 13.66^{\prime \prime} \mathrm{E}$ ) is on the coast of Zhifu Island. Site 2 (S2: $37^{\circ} 32^{\prime} 1.81^{\prime \prime}-37^{\circ} 32^{\prime} 2.73^{\prime \prime} \mathrm{N}, 121^{\circ} 25^{\prime} 34.28^{\prime \prime}-121^{\circ} 25^{\prime} 38.78^{\prime \prime} \mathrm{E}$ ) is on

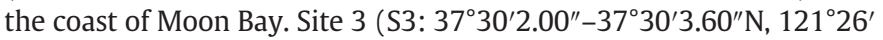
$40.09^{\prime \prime}-121^{\circ} 26^{\prime} 40.26^{\prime \prime} \mathrm{E}$ ) is on the coast of Fisherman Wharf. Site 4 (S4: $37^{\circ} 29^{\prime} 9.51^{\prime \prime}-37^{\circ} 29^{\prime} 10.44^{\prime \prime} \mathrm{N}, 121^{\circ} 38^{\prime} 35.84^{\prime \prime}-121^{\circ} 38^{\prime} 38.88^{\prime \prime} \mathrm{E}$ ) is on the coast of Yangma Island. The selected four sites were affected by different anthropogenic and natural environmental factors and the detailed information was showed in Fig. 1 and Table 1.

\subsection{Sample collection}

Macroalgae and surface seawater samples were taken at the four sites in April 2012. Surface seawater temperature and practical salinity $\left(S_{p}\right)$ were directly measured in situ using a YSI (Yellow Spring Ohio, U.S.A.) water quality meter. During the sampling period, sea temperature ranged from 1 to $8{ }^{\circ} \mathrm{C}$, and $\mathrm{S}_{\mathrm{p}}$ was between 28.6 and $30 \mathrm{psu}$. Three $0.5 \mathrm{~L}$ surface seawater samples were filtered through cellulose acetate membranes (Whatman, $0.45 \mu \mathrm{m}$ ) using a vacuum pump at each site for nutrient concentrations determination. The filtered water samples were poisoned with $\mathrm{HgCl}_{2}$ ( $0.05 \%$ final concentration) to prevent microbial alteration, and then were frozen $\left(-20^{\circ} \mathrm{C}\right)$ until analysis.

A quadrat $(1 \times 1 \mathrm{~m})$ was used to collect macroalgal species. Three quadrats were chosen along the coast of each site and all macroalgal species in three quadrats were collected and identified with the help of a microscope (CKX41, Olympus, Japan) in the laboratory. In total, 20 species of Rhodophyta, 6 species of Phaeophyta and 4 species of Chlorophyta were identified (Appendix I in supplement). Same specimens of the three quadrats were taken for each species. Macroalgae 


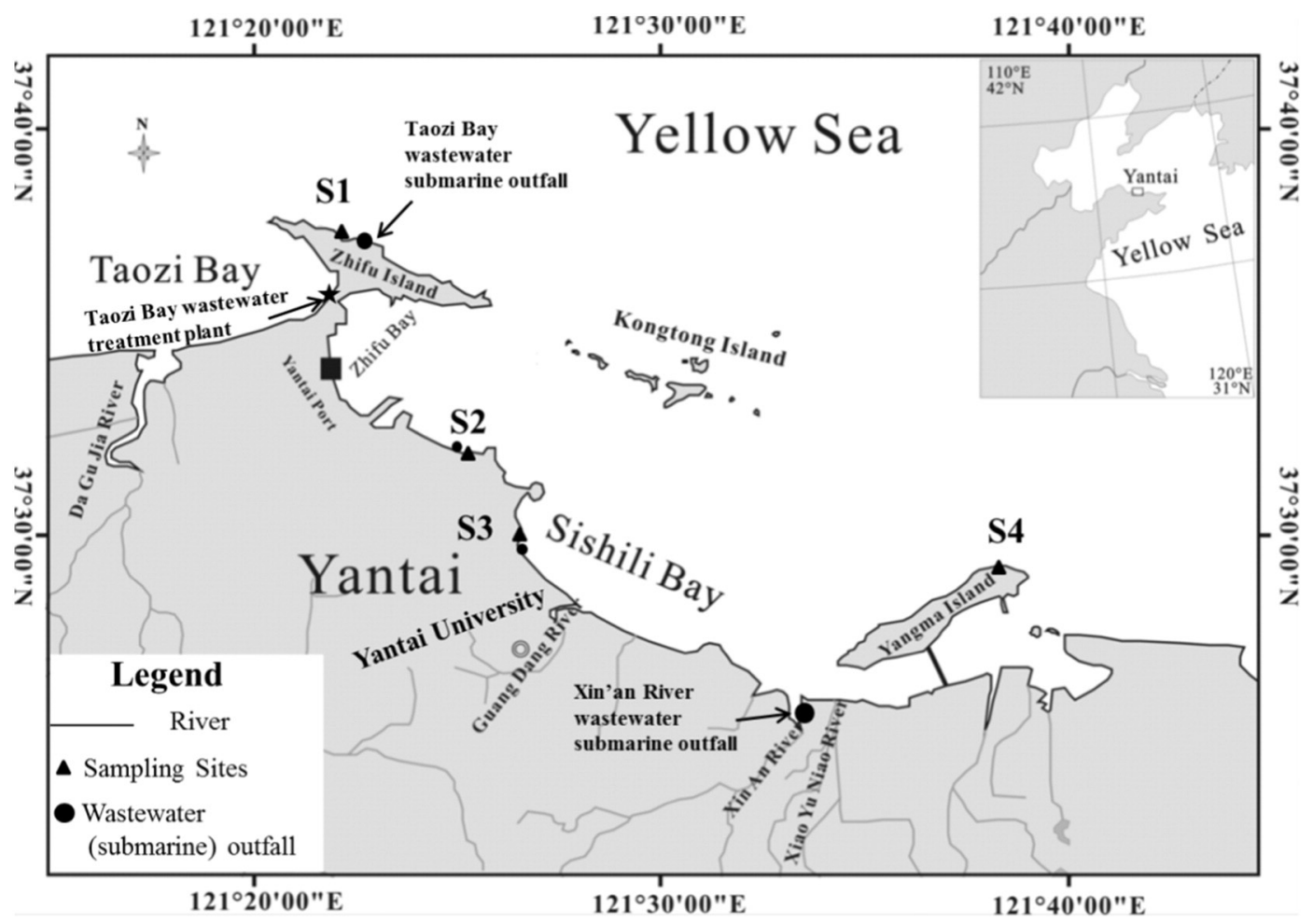

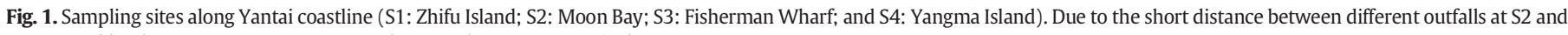
S3, we could only use one spot to represent them on the map, respectively.

were firstly washed in filtered seawater to clean and remove other organisms and were rinsed in Milli-Q water, then were dried in the freeze dryer (Christ ALPHA 1-4 LSC, German) and afterwards the dried specimens of each species were mixed and homogenized by grinding.

\subsection{Total carbon (TC), total nitrogen (TN) and $\delta^{15} \mathrm{~N}$ measurement of algal} tissue

Approximately $0.5-1 \mathrm{mg}$ of grinded macroalgae was placed into a $4 \times 6 \mathrm{~mm}$ tin capsule. TC, TN and $\delta^{15} \mathrm{~N}$ of algal tissue were analyzed with a continuous-flow isotope-ratio mass spectrometer (Delta V Advantage, Thermo Scientific, Germany) coupled to an elemental analyzer (Flash EA1112 Thermo Scientific, Italy). Reference gases were calibrated against International Reference Materials (IAEA-N1, IAEA-N2 and IAEA600 ). The results are expressed relative to atmospheric $\mathrm{N}_{2}$ as a standard of $\delta^{15} \mathrm{~N}$ according to the following equation:

$\delta{ }^{15} \mathrm{~N}$ sample\% $=\frac{\left({ }^{15} \mathrm{~N} /{ }^{14} \mathrm{~N}\right) \text { sample- }\left({ }^{15} \mathrm{~N} /{ }^{14} \mathrm{~N}\right) \text { standard }}{\left({ }^{15} \mathrm{~N} /{ }^{14} \mathrm{~N}\right) \text { standard }} \times 1000$.

Replicate measurements of a laboratory standard (acetanilide, Thermo Scientific) indicated that the analytical errors for samples were $<0.1 \%$ for $\delta^{15} \mathrm{~N}$. The C: $\mathrm{N}$ ratios were determined from the \%TC and \%TN data.

\subsection{Nutrient measurement of seawater samples}

Nutrient concentrations, including nitrate $\left(\mathrm{NO}_{3}-\mathrm{N}\right)$, nitrite $\left(\mathrm{NO}_{2}-\mathrm{N}\right)$, ammonium $\left(\mathrm{NH}_{4}-\mathrm{N}\right)$ and soluble reactive phosphorus $\left(\mathrm{PO}_{4}-\mathrm{P}\right)$, were measured by flow injection analysis (AA3, Bran + Luebbe, Germany). The analysis procedures followed the WOCE (World Ocean Circulation Experiment) Methods Manual WHPO 91-1 (Gordon et al., 1993; JGOFS Protocols, June 1994). The limits of detection were $0.015 \mu \mathrm{M}$ for $\mathrm{NO}_{3}-\mathrm{N}, 0.003 \mu \mathrm{M}$ for $\mathrm{NO}_{2}-\mathrm{N}, 0.04 \mu \mathrm{M}$ for $\mathrm{NH}_{4}-\mathrm{N}$, and $0.02 \mu \mathrm{M}$ for $\mathrm{PO}_{4}-\mathrm{P}$.

\subsection{Data analysis}

A one-way ANOVA and post hoc Tukey HSD tests $(\alpha=0.05)$ were used to determine the significance of differences in TC, TN, C:N and $\delta^{15} \mathrm{~N}$ in algal tissue among different sampling sites.

\section{Results}

\subsection{Nutrient concentrations and composition of seawater at the four sites}

Nutrient concentrations and composition at the four sites are listed in Table 2. The highest DIN and $\mathrm{PO}_{4}-\mathrm{P}$ concentrations occurred at $\mathrm{S} 1$, with $\mathrm{NH}_{4}-\mathrm{N}$ contributing $80 \%$ of DIN. The lowest DIN concentrations were observed at $\mathrm{S} 4$, with $64 \%$ of DIN contribution from $\mathrm{NH}_{4}-\mathrm{N}$. However, $\mathrm{NO}_{3}-\mathrm{N}$ was the dominant composition of DIN at $\mathrm{S} 2$, contributing $60 \%$. $\mathrm{PO}_{4}-\mathrm{P}$ concentrations were low and similar at S2, S3 and S4. DIN:PO 4 ratios exhibited a trend of $\mathrm{S} 2>\mathrm{S} 3>\mathrm{S} 4>\mathrm{S} 1$.

\subsection{Comparison of TN values, C: $N$ ratios and $\delta^{15} N$ values in macroalgal tis- sue at the four sites}

The ranges and averages of TN values, C: $\mathrm{N}$ ratios and $\delta^{15} \mathrm{~N}$ values in macroalgal tissue were shown in Fig. 2 and Table 3. The highest tissue $\mathrm{TN}$, much lower $\mathrm{C}: \mathrm{N}$ ratios, and particularly low $\delta^{15} \mathrm{~N}$ values together with the narrowest TN and C:N ratio ranges occurred at S1, where seawater DIN concentrations were highest (Table 2). A Tukey test among the four sites also showed a significant difference in tissue TN and $\delta^{15} \mathrm{~N}$ between $\mathrm{S} 1$ and the other three sites $(\mathrm{p}<0.05$, Table 4$)$. The average values of tissue TN, C:N and $\delta^{15} \mathrm{~N}$ at S2, S3 and S4 exhibited relatively slight difference ( $p>0.05$, Table 4$)$. Although seawater DIN concentrations were lower at S4 than S2 and S3, tissue TN and $\delta^{15} \mathrm{~N}$ at these sites showed a trend of S4 $>\mathrm{S} 2 \approx \mathrm{S} 3$ and $\mathrm{S} 4>\mathrm{S} 2>\mathrm{S} 3$, respectively. C:N ratios showed an opposite trend to TN. $\delta^{15} \mathrm{~N}$ range (6.3-9.4\%) at S3 was much narrower than the other three sites (Fig. 2, Table 3). 
Table 1

Description of the four sampling sites.

\begin{tabular}{|c|c|c|c|c|}
\hline Sites & Location and characteristic & Use of lands near the sampling sites & Possible sources of contamination & $\begin{array}{l}\text { Photo of sampling sites (wastewater outfalls } \\
\text { are noted) }\end{array}$ \\
\hline $\begin{array}{c}\text { Site } \\
1\end{array}$ & $\begin{array}{l}\text { S1 is on the northern coast of Zhifu Island } \\
\text { with substrate being sand and smooth rock } \\
\text { and macroalga mainly was found on the } \\
\text { rock substrate. Laoye Mountain isolated S1 } \\
\text { from residents' living centers. The Taozi } \\
\text { Bay wastewater treatment plant (WWTP) } \\
\text { is located in the south of the island, and the } \\
\text { treated wastewater is piped to the sea } \\
\text { outside Zhifu Bay by a } 650 \text {-m submarine } \\
\text { wastewater line. S1 is in the waste water } \\
\text { discharge mixing zone of WWTP. }\end{array}$ & $\begin{array}{l}\text { The surround Laoye Moutain is } \\
\text { covered by natural pine woods. }\end{array}$ & $\begin{array}{l}\text { Atmospheric deposition; treated } \\
\text { waste water of sewage, agriculture } \\
\text { and industrial discharged from } \\
\text { WWTP. }\end{array}$ & \\
\hline $\begin{array}{c}\text { Site } \\
2\end{array}$ & $\begin{array}{l}\mathrm{S} 2 \text { is on the coast of Moon Bay with a sand } \\
\text { substrate, where there are two domestic } \\
\text { sewage outfalls with discontinuous } \\
\text { untreated wastewater input near the } \\
\text { beach. The diameter of the two outfalls is } \\
\text { approximately } 1 \mathrm{~m} \text { and distance between } \\
\text { them is approximately } 15 \mathrm{~m} \text {. }\end{array}$ & $\begin{array}{l}\mathrm{S} 2 \text { is a tourist spot surrounded by the } \\
\text { residential living area. }\end{array}$ & $\begin{array}{l}\text { Atmospheric deposition; } \\
\text { discontinuous untreated wastewater } \\
\text { input from the surrounding living } \\
\text { residents; pollution from tourists. }\end{array}$ & \\
\hline $\begin{array}{c}\text { Site } \\
3\end{array}$ & $\begin{array}{l}\mathrm{S} 3 \text { is on the coast of Fisherman Wharf with } \\
\text { a pebble substrate. There are many small } \\
\text { sewage outfalls with continuous untreated } \\
\text { wastewater input around the beach. The } \\
\text { distance between outfalls is around } 2-4 \mathrm{~m} \\
\text { and diameter of each outfall is } \\
\text { approximately } 0.1 \mathrm{~m} \text {. }\end{array}$ & $\begin{array}{l}\mathrm{S} 3 \text { is also surrounded by the } \\
\text { residential living area. There is } \\
\text { bivalve culture in the coast. }\end{array}$ & $\begin{array}{l}\text { Atmospheric deposition; } \\
\text { discontinuous untreated wastewater } \\
\text { input from the surrounding living } \\
\text { residents; the excretion of bivalve } \\
\text { culture. }\end{array}$ & \\
\hline $\begin{array}{r}\text { Site } \\
4\end{array}$ & $\begin{array}{l}\text { S4 is on the coast of Yangma Island with a } \\
\text { pebble substrate, which is a marine } \\
\text { conservation area. Xin'an River } \\
\text { wastewater submarine outfall is in the } \\
\text { southeast of S4 and S4 is not in the mixing } \\
\text { zone's area of sewage discharge. }\end{array}$ & $\begin{array}{l}\text { The Yangma Island has a population } \\
\text { of } 7000 \text { and a number of residents on } \\
\text { the island engage in marine } \\
\text { aquaculture (sea cucumber, abalone) } \\
\text { along the beach. }\end{array}$ & $\begin{array}{l}\text { Atmospheric deposition; pollution } \\
\text { from the living residents; the } \\
\text { excretion of aquaculture. Possible } \\
\text { effects from Xin'an River wastewater } \\
\text { submarine outfall. }\end{array}$ & \\
\hline
\end{tabular}

Considering the interspecies difference of TN and $\delta^{15} \mathrm{~N}$ expression, macroalgal species with presence at least two sites were chosen to compare the tissue TN and $\delta^{15} \mathrm{~N}$ between different sampling sites (Fig. 3). TN values of most species showed a general trend of $\mathrm{S} 1>\mathrm{S} 4 \geq \mathrm{S} 2$ and $\mathrm{S} 3$ and this trend is consistent with the comparison of average values and the ANOVA analysis of all macroalgal species different site (Tables 3, 4). $\delta^{15} \mathrm{~N}$ values analysis of same species at the four sites were also consistent with the trend average $\delta^{15} \mathrm{~N}$ values comparison of all macroalgal tissue, with $\delta^{15} \mathrm{~N}$ values were much lighter in macroalgal species at $\mathrm{S} 1$ (significant different to the other three sites) and were similar in species at S3 and S4 (Fig. 3b; Table 3).

\subsection{Interspecific difference of TN values, $C: N$ ratios and $\delta^{15} N$ values in} macroalgal tissue

TN values, C: $\mathrm{N}$ ratios and $\delta^{15} \mathrm{~N}$ values in macroalgal tissue are influenced not only by nutrient concentrations and sources at different sites but also by interspecific differences within a site. Interspecific

Table 2

Nutrient concentrations $(\mu \mathrm{M})$ and composition at the four sites (DIN: dissolved inorganic nitrogen).

\begin{tabular}{|c|c|c|c|c|c|c|c|}
\hline Sites & & $\mathrm{NO}_{2}-\mathrm{N}$ & $\mathrm{NH}_{4}-\mathrm{N}$ & $\mathrm{NO}_{3}-\mathrm{N}$ & DIN & $\mathrm{PO}_{4}-\mathrm{P}$ & $\mathrm{DIN}: \mathrm{PO}_{4}$ \\
\hline \multirow[t]{2}{*}{ S1 } & Range & $0.68-0.95$ & $25.1-82.3$ & $10.2-12.0$ & $37.4-95.0$ & $0.31-0.41$ & 92.6-103 \\
\hline & Average & 0.79 & 46.4 & 11.1 & 58.2 & 0.38 & 167 \\
\hline \multirow[t]{2}{*}{ S2 } & Range & $0.26-0.37$ & $6.37-11.4$ & $8.68-19.4$ & $18.0-26.0$ & $0.03-0.04$ & $522-769$ \\
\hline & Average & 0.31 & 8.92 & 13.9 & 23.1 & 0.03 & 666 \\
\hline \multirow[t]{2}{*}{ S3 } & Range & $0.15-0.18$ & $7.49-8.62$ & $2.87-4.69$ & $11.7-12.7$ & $0.02-0.04$ & $329-491$ \\
\hline & Average & 0.17 & 7.98 & 4.02 & 12.2 & 0.03 & 390 \\
\hline \multirow[t]{2}{*}{ S4 } & Range & $0.08-0.15$ & $5.45-7.43$ & $1.91-4.95$ & $7.44-12.5$ & $0.04-0.07$ & $138-309$ \\
\hline & Average & 0.12 & 6.27 & 3.48 & 9.86 & 0.05 & 219 \\
\hline
\end{tabular}



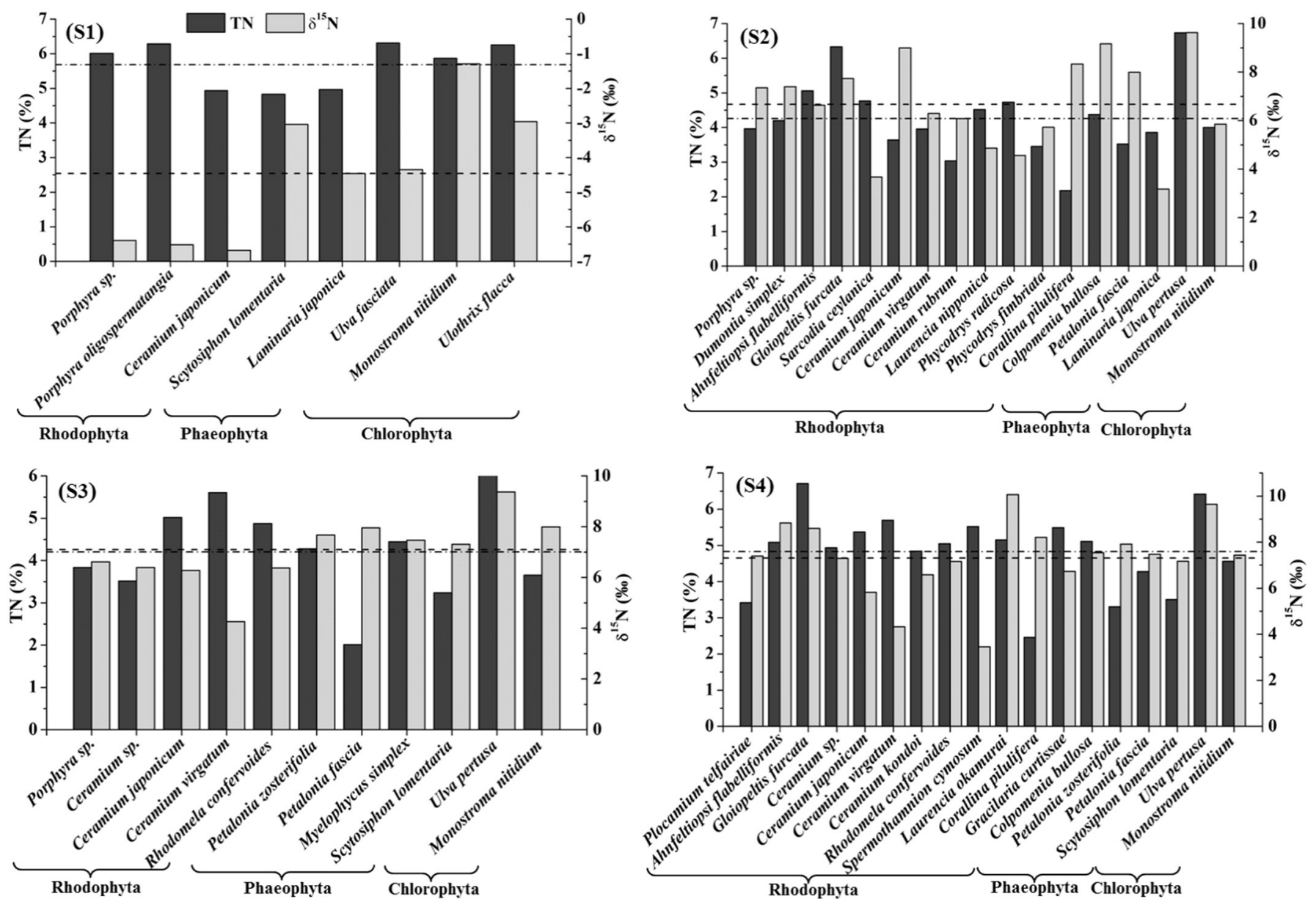

Fig. 2. TN and $\delta^{15} \mathrm{~N}$ values of macroalgal tissue at the four sites; and the average values of TN and $\delta^{15} \mathrm{~N}$ (Table 2 ) were shown with dash dot line and dash line, respectively.

differences were compared at the four sites (Table 5 and Fig. 2). Species of Phaeophyta generally displayed the lowest tissue TN and highest C:N ratios at each site compared with the species of Chlorophyta and Rhodophyta (Table 5), while the average TN and C: $\mathrm{N}$ of Chlorophyta and Rhodophyta were more similar at the four sites. The average $\delta^{15} \mathrm{~N}$ value of Rhodophyta was considerably lighter than which of Chlorophyta and Phaeophyta, particularly at S1 (Table 5 and Fig. 2).

Interspecific differences in TN and $\delta^{15} \mathrm{~N}$ also existed within each phylum. Among the Rhodophyta, tissue TN in Gloiopeltis furcata at S2 was considerably higher than the average TN value, while its value in Corallina pilulifera at S2 $(2.18 \%)$ and S4 $(2.46 \%)$ was considerably lower than the average. Among the Phaeophyta species, tissue TN in P. fascia (2.01\%) at S3 was much lower than the average value (4.23\%). Among the Chlorophyta species, tissue TN at S2-S4 was considerably higher in Ulva pertusa than in Monostroma nitidium (Fig. 2).

Table 3

TN, C:N and $\delta^{15} \mathrm{~N}$ values in macroalgal tissue at four sites (TC: total carbon; TN: total nitrogen; $\mathrm{n}$ : the number of species).

\begin{tabular}{lllll}
\hline Sites & & TN $(\%)$ & $\mathrm{C}: \mathrm{N}$ & $\delta^{15} \mathrm{~N}(\%)$ \\
\hline S1 $(\mathrm{n}=8)$ & Range & $4.83-6.31$ & $6.34-7.49$ & -6.7 to -1.3 \\
& Average & 5.68 & 6.81 & -4.5 \\
S2 $(\mathrm{n}=17)$ & Range & $2.18-6.73$ & $5.14-9.52$ & $3.2-9.6$ \\
& Average & 4.26 & 7.56 & 6.7 \\
S3 $(\mathrm{n}=11)$ & Range & $2.01-6.10$ & $5.41-10.9$ & $6.3-9.4$ \\
& Average & 4.23 & 8.02 & 7.1 \\
S4 $(\mathrm{n}=18)$ & Range & $2.46-6.71$ & $4.87-10.9$ & $3.5-10.1$ \\
& Average & 4.83 & 7.02 & 7.3 \\
\hline
\end{tabular}

Tissue $\delta^{15} \mathrm{~N}$ values in U. pertusa (Chlorophyta) at S2-S4 and Laurencia okamurai (Rhodophyta) at S4 were higher than other species at the same sites, while in Sarcodia ceylanica (Rhodophyta) at S2, in Spermothamnion cymosum (Rhodophyta) at S4 and in Laminaria japonica (Phaeophyta) at S1 and S2 were significantly lower than other species. A number of species exhibited variable signals at different sites. For example, although tissue $\delta^{15} \mathrm{~N}$ of Ceramium japonicum was always higher than Ceramium virgatum (Rhodophyta) at S2-S4, and higher than in Porphyra sp., Ahnfeltiopsi flabelliformis, G. furcata (Phodophyta) and M. nitidium (Chlorophyta) at S2, but lower than tissue $\delta^{15} \mathrm{~N}$ of these species at the other three sites (Fig. 2).

\section{Discussions}

\subsection{Factors related to the $T N$ and $\delta^{15} N$ modification in algal tissue}

Algal tissue TN and $\delta^{15} \mathrm{~N}$ are mainly affected by environmental and metabolic factors. In our study, environmental factors mainly referred

Table 4

Turkey test of ANOVA for TN and $\delta^{15} \mathrm{~N}$ values in macroalgal tissue among four sites.

\begin{tabular}{lllll}
\hline Factors & Sites & S2 & S3 & S4 \\
\hline TN & S1 & $0.014^{*}$ & $0.025^{*}$ & 0.242 \\
& S2 & - & 1.000 & 0.388 \\
\multirow{2}{*}{$\delta^{15} \mathrm{~N}$} & S3 & - & - & 0.467 \\
& S1 & $0.000^{*}$ & $0.000^{*}$ & $0.000^{*}$ \\
& S2 & - & 0.937 & 0.693 \\
& S3 & - & - & 0.981 \\
\hline
\end{tabular}

* Difference is significant at the 0.05 level. 

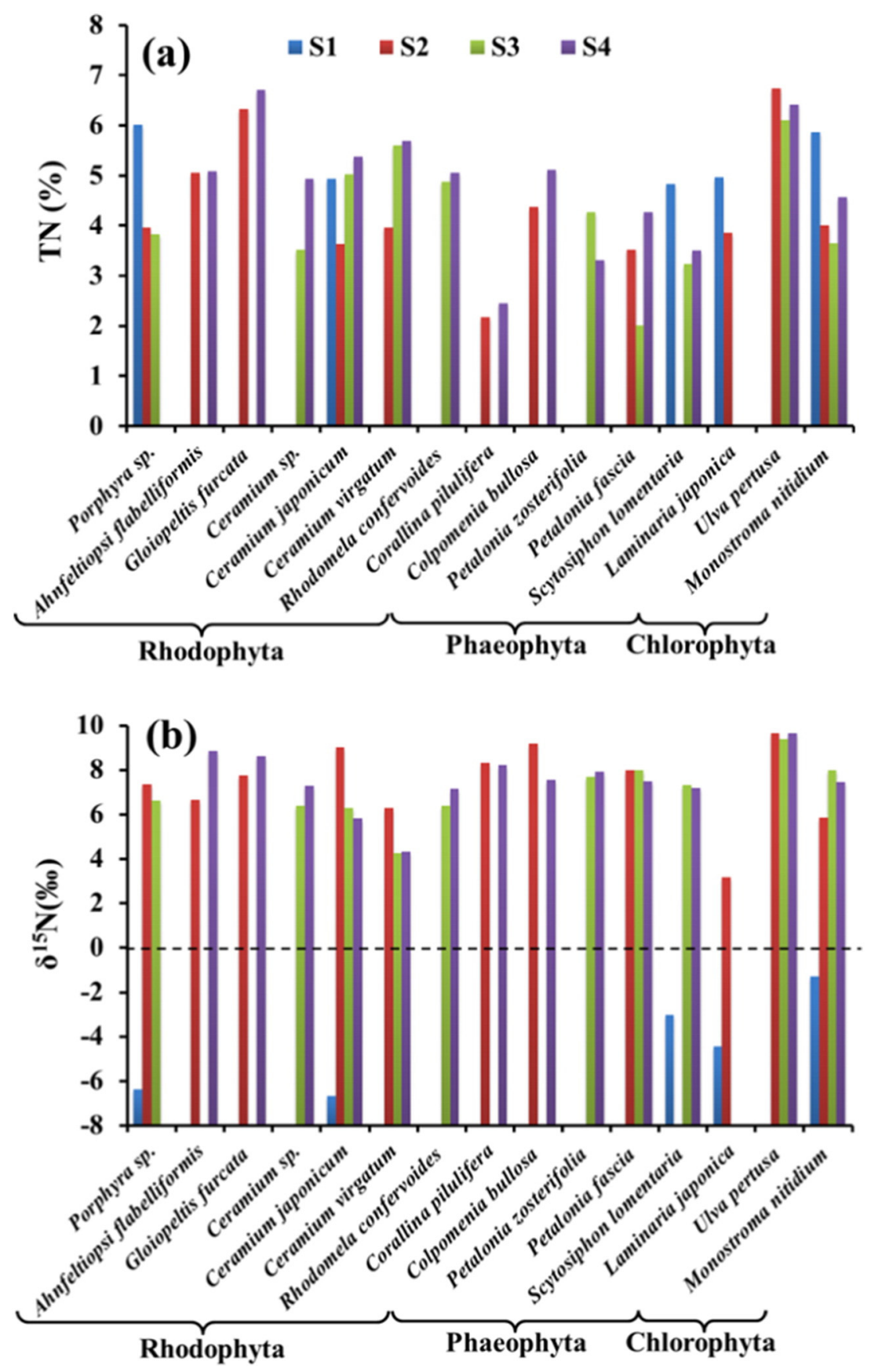

Fig. 3. Comparison of $\mathrm{TN}(\mathrm{a})$ and $\delta^{15} \mathrm{~N}$ (b) of same macroalgal species among the four sites.

to seawater nutrient concentrations, as no obvious difference of salinity and ST was observed among the four study sites. Nutrient levels can affect the metabolism of nitrogen and carbon in macroalgae (Turpin, 1991), and nitrogen could be accumulated in tissue when DIN concentration is beyond requirements (Fong et al., 2004). The elevated $\mathrm{N}$ content $(>2 \%)$, low C:N ratios $(<11)$ in all macroalgal specie collected at the four sites together with the higher DIN concentrations revealed that the macroalgae were not $\mathrm{N}$-limited at the four sites (Lapointe and Bedford, 2010; Collado-Vides et al., 2013; Ochoa-Izaguirre and Soto-Jiménez, 2015). The highest TN content (5.68\%), lowest C:N ratios (6.81) and the narrower TN and $\mathrm{C}: \mathrm{N}$ ranges of macroalgal species at S1indicated that nitrogen in algal tissue is even close to saturation state, as a result of high seawater nitrogen level. Besides of DIN concentrations, P is also important for the growth of macroalgae. The tissue TN comparisons among the four sites were consistent with the $\mathrm{PO}_{4}$-P concentrations and the DIN : $\mathrm{PO}_{4}-\mathrm{P}$ ratios, however were not consistent with the DIN concentrations at S2, S3 and S4, implying the potential impacts from P limitation at these three sites (Piñón-Gimate et al., 2008, 2009). Due to the lack of algal tissue TP, it is impossible to compare the algal tissue TN:TP ratios with seawater DIN:PO 4 -P ratios in our study. However seawater $\mathrm{DIN}: \mathrm{PO}_{4}-\mathrm{P}$ ratios were much higher at the four sites in our study than seawater DIN:PO ${ }_{4}-\mathrm{P}$ ratios and tissue TN:TP ratios of other places (see Table 6 in Larned, 1998). The seawater DIN:PO $-\mathrm{P}$ ratios at S2 and S3 were even much higher than the highest macroalgal tissue TN:TP reported in field conditions (see Table 2 in Larned, 1998). Thus, it was supposed that the growth and absorption of nitrogen of algae at S2, S2 and 
Table 5

Comparison of macroalgal tissue TN, C:N and $\delta^{15} \mathrm{~N}$ values between different phyla (n: the number of species).

\begin{tabular}{llllll}
\hline Sites & Phyla & & TN $(\%)$ & C:N & $\delta{ }^{15} \mathrm{~N}(\%)$ \\
\hline S1 & Rhodophyta & Range & $4.93-6.29$ & $6.57-6.82$ & -6.7 to -6.4 \\
& $(\mathrm{n}=3)$ & Average & 5.74 & 6.66 & -6.5 \\
& Phaeophyta & Range & $4.83-4.97$ & $7.25-7.49$ & -4.5 to -3.0 \\
& $(\mathrm{n}=2)$ & Average & 4.90 & 7.37 & -3.8 \\
& Chlorophyta & Range & $5.87-6.31$ & $6.34-7.05$ & -4.4 to -1.3 \\
& $(\mathrm{n}=3)$ & Average & 6.14 & 6.60 & -2.9 \\
S2 & Rhodophyta(n $=12)$ & Range & $2.18-6.33$ & $5.14-9.50$ & $3.7-9.0$ \\
& & Average & 4.15 & 7.46 & 6.5 \\
& Phaeophyta & Range & $3.52-4.37$ & $7.75-9.52$ & $3.2-9.2$ \\
& (n=3) & Average & 3.92 & 8.58 & 6.8 \\
& Chlorophyta & Range & $4.00-6.73$ & $5.20-7.99$ & $5.9-9.6$ \\
& (n=2) & Average & 4.26 & 7.56 & 6.7 \\
S3 & Rhodophyta & Range & $3.51-5.61$ & $6.79-9.01$ & $4.3-6.6$ \\
& (n=5) & Average & 4.57 & 7.72 & 6.0 \\
& Phaeophyta & Range & $2.01-4.44$ & $6.01-10.9$ & $7.3-8.0$ \\
& (n=4) & Average & 3.49 & 8.72 & 7.6 \\
& Chlorophyta & Range & $3.66-6.10$ & $5.41-9.29$ & $8.0-9.4$ \\
& (n=2) & Average & 4.23 & 8.02 & 7.1 \\
S4 & Rhodophyta & Range & $2.46-6.71$ & $4.87-11.0$ & $3.5-10.1$ \\
& (n=12) & Average & 4.98 & 6.79 & 7.0 \\
& Phaeophyta & Range & $3.31-5.11$ & $5.86-9.66$ & $7.2-7.9$ \\
& (n=4) & Average & 4.05 & 7.79 & 7.5 \\
& Chlorophyta & Range & $4.56-6.41$ & $5.37-8.27$ & $7.4-9.6$ \\
& (n=2) & Average & 4.83 & 7.02 & 7.3 \\
\hline \multirow{4}{*}{ (n) } & & & & &
\end{tabular}

S4 were limited by $\mathrm{PO}_{4}-\mathrm{P}$ concentrations. This supposition get support from results of Han and Liu (2014) which stated that growth of macroalgae at $\mathrm{S} 1, \mathrm{~S} 3$ and $\mathrm{S} 4$ were affected by $\mathrm{PO}_{4}-\mathrm{P}$ concentration.

Impacts of metabolism to nitrogen and carbon in macrogalgae are species-specific owing to different storage capacity and nutrient requirements for growth (Hanisak and Harlin, 1978; Larned, 1998; Deutsch and Voss, 2006). The higher TN of algal tissue of Rhodophyta and Chlorophyta species compared to Phaeophyta species at the four sites along the Yantai coast showed different nitrogen storage between phyla. This is supported by the report that species of Rhodophyta and Chlorophyta had a competitive advantage (Kraufvelin et al., 2010; Han and Liu, 2014). Some filamentous and foliose macroalgal groups showed elevated $\mathrm{N}$ content and lower $\mathrm{C}: \mathrm{N}$ ratios as characterized by simplest structure and/or a higher surface area (Ochoa-Izaguirre and Soto-Jiménez, 2015), which explained $U$. pertusa in our study showed higher tissue TN at S2, S3 and S4. Besides, different from species such as Prophyra sp. and Ceramium Japonicum which showed lower tissue TN at S2 and S3 compared to S4 as a result of P limitation, the tissue TN and C:N ratios of $U$. pertusa, however, seemed mainly consistent with the seawater DIN concentrations (Fig. 2), indicating the high nitrogen uptake and demand (Pedersen and Borum, 1996; Raven and Taylor, 2003; Teichberg et al., 2008, 2010). C. pilulifera, Scytosiphon lomentaria and Petalonia fascia all showed lower TN values and higher C:N ratios compared to other macroalgal species, might be related to the low ability of DIN absorption and/or quick nitrogen release (Tyler et al., 2005; Tyler and McGlathery, 2006).

Tissue $\delta^{15} \mathrm{~N}$ values were also affected by seawater nutrient and metallic factors. DIN source was undoubtedly the dominant impact factor for the $\delta^{15} \mathrm{~N}$ values of algal tissue at the four sites in our study. The significant differences of $\delta^{15} \mathrm{~N}$ values between $\mathrm{S} 1$ and the other three sites were caused by its unique DIN sources (Tables 1,4 ). Although the impact of nutrient concentrations and nitrogen status on macroalgal fractionation remains controversial, physiological fractionation could be significant in $\mathrm{N}$ rich environment (Umezawa et al., 2007; Dailer et al., 2010; Ochoa-Izaguirre and Soto-Jiménez, 2015). Variations of $\delta^{15} \mathrm{~N}$ values between macroalgal species and phyla at the same site indicated the effects from fractionation (Fig. 2). For example, macroalgae species of Rhodophyta showed lower $\delta^{15} \mathrm{~N}$ values compared to the other two phyla species, and the more obvious difference at S1 were related to the high DIN concentration.
4.2. Selecting the effective macroalgae as indicators to trace nitrogen sources

Several foliose and filamentous macroalgal species could more efficiently reflect the nitrogen sources in the water column as they were characterized by having faster nitrogen uptake and growth rates, and were more sensitive to changes in environmental conditions, chemical forms and isotopic composition of $\mathrm{N}$ in the water (Deutsch and Voss, 2006; Teichberg et al., 2008; Dailer et al., 2010; Ochoa-Izaguirre and Soto-Jiménez, 2015). However significant different tissue $\delta^{15} \mathrm{~N}$ values were found for species of same functional groups or even same genus. For example, in the Chlorophyta-Filamentous uncorticated function, the determination factor showed higher affinity between $\delta^{15} \mathrm{~N}$-DIN and $\delta{ }^{15} \mathrm{~N}$-macroalgae in Bryopsis pennatula $\left(\mathrm{R}^{2}=0.57\right)$, but much lower in Bryopsis corticulans $\left(\mathrm{R}^{2}=0.02\right.$ ) (Ochoa-Izaguirre and SotoJiménez, 2015). As a result, here we only compared the difference between species and assessed the indicative macroalgal species on the Yantai coast, rather than their function differences.

Macroalgal tissue $\delta^{15} \mathrm{~N}$ varied among species because of fractionation during uptake, assimilation or release of nitrogen (Tyler and McGlathery, 2006). Fractionation during nitrogen uptake leads to depletion of $\delta^{15} \mathrm{~N}$ in the algal tissues compared to seawater nitrogen. L. okamurai, G. furcata and $U$. pertusa had the highest TN and $\delta^{15} \mathrm{~N}$ values compared to other species at S2, S3 and S4 where DIN concentrations were relatively lower (Fig. 2). The high TN implied the high uptake and/or low release of nitrogen, and high $\delta^{15} \mathrm{~N}$ values indicated the negligible fractionation during the nitrogen uptake. As a result, these three species were proven to be ideal indicative species in relatively lower DIN concentration sites along the Yantai coast. This is supported by the previous results that some Chlorophyta species such as Ulva sp. were characterized by high capacity of nitrate storage and almost no fractionation, and could be used for nitrogen sources tracing (Cohen and Fong, 2005; Dudley et al., 2010; Raimonet et al., 2013). Unfortunately, there is no U. pertusa at S1 where the DIN concentration was relatively higher, so we couldn't confirm the use of $U$. pertusa for nitrogen tracing in high DIN levels. Compared to these three species, some species at S2, S3 and S4 also showed relatively high TN content and the variation of tissue $\delta^{15} \mathrm{~N}$ was not obvious enough to affect the nitrogen sources estimation, and could also be used for nitrogen sources tracing (Fig. 2). For example, Prophyra sp., Dumontia simplex and A. flabelliformis of Rhodophyta, Colpomenia bullosa of Phaeophyta and M. nitidium of Chlorophyta at S2; Prophyra sp., Ceramium sp., and Rodomela confervoides of Rhodophyta, Petalonia zosterifolia, Myelophycus simplex and S. lomentaria of Phaeophyta and M. nitidium of Chlorophyta at S3; A. flabelliformis, Ceramium sp., Ceramium kondoi, Rhodomela confevoides and Gracilaria curissae of Rhodophyta, C. bullosa, P. zosterifolia and S. lomentaria of Phaeophyta and M. nitidium of Chlorophyta at S4. At S1, only S. lomentaria and $M$. nitidium showed relatively higher TN content and $\delta{ }^{15} \mathrm{~N}$ values, indicated high nitrogen storage and lower fractionation compared to other species (Fig. 2).

Species that were not suitable for nitrogen sources tracing in our study were also discussed. High TN together with low $\delta^{15} \mathrm{~N}$ values might be related to the $\delta^{15} \mathrm{~N}$ depletion of fractionation during nitrogen uptake. The three Rhodophyta species and Ulva fasciata at S1, S. ceylanica at S2, and S. cymosum at S4 all showed this situation. The depletion was more obvious at S1 as a result of its high DIN concentration. Porphyra sp. could be used for nitrogen source tracing at S2 and S3 but not at S1. C. japonicum and C. virgatum both showed high TN and low $\delta^{15} \mathrm{~N}$ values at S3 and S4, but relatively higher $\delta^{15} \mathrm{~N}$ values at S2, implicated that the fractionation during nitrogen uptake might be varied between different nitrogen concentrations and compositions. Higher $\mathrm{NH}_{4}$ $\mathrm{N}$ proportion at S2 could explain this. Studies of fractionation factors during $\mathrm{N}$ uptake obtained of $3 \%$ o for $\mathrm{NH}_{4}-\mathrm{N}$ uptake and of $0 \%$ or $\mathrm{NO}_{3}-$ $\mathrm{N}$ uptake (Kaldy, 2011). It seemed that the fractionation was more obvious during $\mathrm{NH}_{4}-\mathrm{N}$ uptake. The obvious fractionation of $C$. japonicum at 
S1 further proved this. As a result, $C$. japonicum and $C$. virgatum are not ideal indicators on the Yantai coast with higher $\mathrm{NH}_{4}-\mathrm{N}$ composition, but might be used in environment with $\mathrm{NO}_{3}-\mathrm{N}$ as dominant DIN forms. Species such as $C$. pilulifera and $P$. fascia with low TN and high $\delta^{15} \mathrm{~N}$ values might be related to the low nitrogen uptake capability and/or quick nitrogen release. Without the lab culture experiment, it's difficult to estimate whether the fractionation happened during nitrogen release or whether these two species could reflect DIN variation in time, so it should be cautious to use these two species as indicator.

L. japonica showed relatively lower $\mathrm{TN}$ and $\delta^{15} \mathrm{~N}$ compared to other species. L. japonica is a perennial alga with relatively lower metabolic rate and localized terminal meristem, and the fresh tissue at the bottom showed different $\delta^{15} \mathrm{~N}$ values to the aged tissue. The $\delta^{15} \mathrm{~N}$ values of the whole thallus couldn't reflect the realistic $\delta{ }^{15} \mathrm{~N}$-DIN of the surrounding water column. This has been found in the study of other perennial algae, such as Fucus vesiculosus (Deutsch and Voss, 2006; Viana and Bode, 2013; Carballeira et al., 2014), Gracilara (Thornber et al., 2008), and Ecklonia radiate (Gartner et al., 2002).

\subsection{Dominant nitrogen sources of the Yantai coast}

The nitrogen sources tracing by using $\delta^{15} \mathrm{~N}$ values was mainly based on the $\delta^{15} \mathrm{~N}$ value variations among different nitrogen sources. Considering the physical mixing and biogeochemical processes, the nitrogen sources estimation should combine the $\delta^{15} \mathrm{~N}$ values and nitrogen sources. Without the $\delta^{15} \mathrm{~N}$ value of each nitrogen source along the Yantai coast, we could only discuss the dominant nitrogen sources in our study. Besides, the seawater DIN concentration together with the algal TN and C:N analysis indicated no DIN depletion at the four sites, so the preferred use of other dissolved forms is not likely to occur (Tyler et al., 2005). The nitrogen sources based on the analysis of macroalgal tissue $\delta^{15} \mathrm{~N}$ in our study are mainly about the DIN sources.

The Turkey test showed obvious difference of algal tissue $\delta^{15} \mathrm{~N}$ between $\mathrm{S} 1$ and the other three sites with much lighter $\delta^{15} \mathrm{~N}$ at $\mathrm{S} 1$ (Table 4). S1 was located in the north of Zhifu Island, where is the wastewater discharge mixing zone's area of Taozi Bay WWTP. The wastewater from the WWTP includes treated sewage, agriculture and industrial water along the Yantai coast and the loading is about $20 \mathrm{t} \mathrm{d}^{-1}$ with $\mathrm{NH}_{3}-\mathrm{N}$ loading of about $5.3 \mathrm{t} \mathrm{d}^{-1}$ (Zhang and Wang, 2010; Fu et al., 2010). The high $\mathrm{NH}_{4}-\mathrm{N}$ concentration at $\mathrm{S} 1$ indicated impacts from the discharge of wastewater. The negative values of algal $\delta^{15} \mathrm{~N}$, however implied that dominant nitrogen loadings might come from fertilizer usage in agriculture or industrial wastewater, instead of sewage or agricultural/marine culture. Yantai is a principal producer of chemical fertilizer in China with more than 40 fertilizer factories in the city. NPK compound fertilizer is the dominant product of these factories. Our lab analysis showed that the $\delta^{15} \mathrm{~N}$ range of fertilizer in Yantai is $-0.46-2.21 \%$, close to the macroalgal tissue $\delta^{15} \mathrm{~N}$. Fractionation might also happen in the wastewater treatment (anaerobic-anoxicoxic process), and affected tissue $\delta^{15} \mathrm{~N}$, but more studies are needed to prove it.

In comparison, tissue $\delta^{15} \mathrm{~N}$ values of macroalgae at S2, S3 and S4 were highly similar (Table 3 ), although nutrient levels in seawaters were slightly different at these three sites (Table 2). The average values of tissue $\delta^{15} \mathrm{~N}$ values at the three sites were between $6.67 \%$ and $7.31 \%$, indicating the influence of sewage discharge or aquaculture (Kendall, 1998; Gartner et al., 2002; Savage and Elmgren, 2004; Dailer et al., 2010).

There are domestic sewage outfalls near to S2 and S3, and the sewage is mainly from residential district and restaurants which result in high DIN concentrations (Tables 1, 2). Except for the domestic sewage input, S3 is also affected by the excretion of bivalve culture in the coast. The DIN composition analysis of seawater close to the Yantai coast showed that $\mathrm{NH}_{4}-\mathrm{N}$ was the dominant DIN form in the aquaculture affected area, and $\mathrm{NO}_{3}-\mathrm{N}$ proportion of sewage water was higher than aquaculture area (Zhao et al., 2000; Zhou, 2000). Although similar tissue $\delta^{15} \mathrm{~N}$ values occurred at S2 and S3, the higher seawater DIN concentration with higher $\mathrm{NO}_{3}-\mathrm{N}$ proportion at $\mathrm{S} 2$, and the lower seawater DIN concentration with higher $\mathrm{NH}_{4}-\mathrm{N}$ proportion at $\mathrm{S} 3$ implied that sewage discharge was heavier at $\mathrm{S} 2$, and $\mathrm{S} 3$ was also affected by the aquaculture.

S4 is located in the north of Yangma Island, which is in a marine conservation area. The tissue $\delta^{15} \mathrm{~N}$ values at S4 (average: 7.3\%。; Fig. 2) also indicated a signal of sewage and/or aquaculture impact. During the survey, we found three potential DIN sources: 1) some marine aquaculture activity (sea cucumber, abalone) in littoral zone at S4, the aquaculture waste (e.g., food and excreta) might increase the concentrations of DIN; 2) Xin'an River wastewater submarine outfall is in the southeast of S4; and 3) sewage discharge from the residents in Yangma Island might affect DIN concentrations. As S3, the relatively lower DIN concentration with higher $\mathrm{NH}_{4}-\mathrm{N}$ propotion at $\mathrm{S} 4$ also indicated the DIN sources from both sewage and aquaculture. In a summary, our results suggested that DIN along the Yantai coasts were affected by three types of DIN inputs, the agricultural fertilizer usage and factorial wastewater input at S1, the sewage discharge at S2, and the sewage discharge together with aquaculture effects at S3 and S4.

\section{Conclusions}

Macroalgal tissue TN and $\delta^{15} \mathrm{~N}$ values at four sites along the Yantai coast were affected by nutrient concentrations and composition, and metabolic activity of species. High DIN concentration at S1 resulted in the high TN, lighter $\delta^{15} \mathrm{~N}$ and obvious fractionation during DIN uptake. P limited the tissue TN values at S2, S3 and S4. Many species with negligible or no obvious fractionation could be used for DIN sources tracing in environment the lower DIN concentrations (S2, S3 and S4) of the Yantai coast. Among them, L. okamurai, G. furcata and U. pertusa were ideal species. The choice of species in higher DIN concentration should be more cautious and only S. lomentaria and M. nitidium could be used as indicators at S1 in our study. The DIN sources at the four sites along the Yantai coast were classified into three types namely the agricultural fertilizer usage and factorial wastewater input at S1, the sewage discharge at S2, and the sewage discharge together with aquaculture impacts at S3 and S4.

Supplementary data to this article can be found online at http://dx. doi.org/10.1016/j.scitotenv.2015.10.059.

\section{Acknowledgments}

The authors thank Gaël Guillou for helping in the isotope ratio analysis of the samples and Dr. Qiuying Han for her helping in the identification of macroalgae species. This work was jointly funded by the Natural Science Foundation of China (41106101 and 41376121), the Strategic Priority Research Program of the Chinese Academy of Sciences (XDA11020405) and the Natural Science Foundation of Shandong Province (JQ201414).

\section{References}

Bricker, S.B., Longstaff, B., Dennison, W., Jones, A., Boicourt, K., Wicks, C., Woerner, J., 2008. Effects of nutrient enrichment in the nation's estuaries: a decade of change. Harmful Algae 8, 21-32.

Carballeira, C., Rey-Asensio, A., Carballeira, A., 2014. Interannual changes in $\delta^{15} \mathrm{~N}$ values in Fucus vesiculosus L. Mar. Pollut. Bull. 85, 141-145.

Carballeira, C., Viana, I.G., Carballeira, A., 2013. $\delta^{15} \mathrm{~N}$ values of macroalgae as an indicator of the potential presence of waste disposal from land-based marine fish farms. J. Appl. Phycol. 25, 97-107.

Cohen, R.A., Fong, P. 2004. Nitrogen uptake and assimilation in Enteromorpha intestinalis (L.) ink (cChlorophyta): using $\delta^{15} \mathrm{~N}$ to determine preference during simultaneous pulses of nitrate and ammonium. J. Exp. Mar. Biol. Ecol. 309, 67-77.

Cohen, R.A., Fong P., 2005. Experimental evidence supports the use of $\delta^{15} \mathrm{~N}$ content of the opportunistic green macroalga Enteromorpha Intestinalis (Chlorophyta) to determine nitrogen sources to estuaries. J. Phycol. 41, 287-293.

Collado-Vides, L., Avila, C., Blair, S., Leliaert, F., Rodriguez, D., Thyberg, T., Schneider, S., Rojas, J., Sweeney, P., Drury, C., Lirman, D., 2013. A persistent bloom of Anadyomene 
J.V. Lamouroux (Anadyomenaceae, Chlorophyta) in Biscayne Bay, Florida. Phycologia $52(4), 19-20$.

Costanzo, S.D.O., Donohue, M.J., Dennison, W.C., Loneragan, N.R., Thomas, M., 2001. A new approach for detecting and mapping sewage impacts. Mar. Pollut. Bull. 42, 149-156.

Dailer, M.L., Knox, R.S., Smith, J.E., Napier, M., Smith, C.M., 2010. Using $\delta^{15} \mathrm{~N}$ values in algal tissue to map locations and potential sources of anthropogenic nutrient inputs on the island of Maui, Hawai'i, USA. Mar. Pollut. Bull. 60 (5), 655-671.

Derse, E., Knee, K.L., Wankel, S.D., Kendall, C., Berg, C.J., Payta, A., 2007. Identifying sources of nitrogen to Hanalei Bay, Kauai, utilizing the nitrogen isotope signature of macroalgae. Environ. Sci. Technol. 41, 5217-5223.

Deutsch, B., Voss, M., 2006. Anthropogenic nitrogen input traced by means of $\delta^{15} \mathrm{~N}$ values in macroalgae: results from in-situ incubation experiments. Sci. Total Environ. 366, 799-808.

Dudley, B.D., Shima, J.S., 2010. Algal and invertebrate bioindicators detect sewage effluent along the coast of Titahi Bay Wellington, New Zealand. N. Z. J. Mar. Freshw. Res. 44, 39-51.

Dudley, B.D., Barr, N.G., Shima, J.S., 2010. Influence of light intensity and nutrient source on $\delta^{13} \mathrm{C}$ and $\delta^{15} \mathrm{~N}$ signatures in Ulva pertusa. Aquat. Biol. 9, 85-93.

Fong, P., Fong, J.J., Fong, C.R., 2004. Growth, nutrient storage, and release of dissolved organic nitrogen by Enteromorpha intestinalis in response to pulses of nitrogen and phosphorus. Aquat. Bot. 78, 83-95.

Fu, H., Liu, Y.J., Sun, H.K., Zuo, H., 2010. Discussion of source items of diffusion model in marine environmental impact assessment for wastewater treatment plant. Trans. Oceanol. Limnol. 4, 47-52 (in Chinese with English abstract).

Gartner, A., Lavery, P., Smit, A.J., 2002. Use of $\delta^{15} \mathrm{~N}$ signatures of different functional forms of macroalgae and filter feeders to reveal temporal and spatial patterns in sewage dispersal. Mar. Ecol. Prog. Ser. 235, 63-73.

Gordon, L.I., Jennings, J.C., Ross Jr., A.A., Krest, J.M., 1993. A Suggested Protocol for Continuous Flow Automated Analysis of Seawater Nutrients (Phosphate, Nitrate, Nitrite and Silicic Acid) in the WOCE Hydrographic Program and the Joint Global Ocean Fluxes Study. WOCE Hydrographic Program OfPce, Methods Manual WHPO, p. 91-1.

Han, Q.Y., Liu, D.Y., 2014. Temporal and spatial variations in the distribution of macroalgal communities along the Yantai coast, China. Chin. J. Oceanol. Limnol. 32, 595-607.

Hanisak, M.D., Harlin, M.M., 1978. Uptake of inorganic nitrogen by Codium fragil subsp. tomentosoides (Chlorophyta). J. Phycol. 14, 450-454.

Hao, Y.J., Tang, D.L., Yu, L., Xing, Q.G., 2011. Nutrients and chlorophyll- $a$ anomalies in redtide periods of 2003-2008 in the Sishili Bay, China. Chin. J. Oceanol. Limnol. 29, 664-673.

Heaton, T.H.E., 1986. Isotopic studies of nitrogen pollution in the hydrosphere and atmosphere: a review. Chem. Geol. 59, 87-102.

Howarth, R., Chan, F., Conley, D.J., Garnier, J., Doney, S.C., Marino, R., Billen, G., 2011. Coupled biogeochemical cycles: eutrophication and hypoxia in temperate estuaries and coastal marine ecosystem. Front. Ecol. Environ. 9, 18-26.

Kaldy, J., 2011. Using a macroalgal $\delta^{15} \mathrm{~N}$ bioassay to detect cruise ship wastewater effluent inputs. Mar. Pollut. Bull. 62, 1762-1771.

Kamer, K., Fong, P., Kennison, R.L., Schiff, K., 2004. The relative importance of sediment and water column supplies of nutrients to the growth and tissue nutrient content of the green macroalga Enteromorpha intestinalis along an estuarine resource gradient. Aquat. Ecol. 38, 45-56.

Kendall, C., 1998. Tracing nitrogen sources and cycling in catchments. In: Kendall, C., McDonnell, J.J. (Eds.), Catchment Hydrology. Elsevier, New York, pp. 519-576.

Kraufvelin, P., Lindholm, A., Pedersen, M.F., Kirkerud, L.A., Bonsdorff, E., 2010. Biomass, diversity and production of rocky shore macroalgae at two nutrient enrichment and wave action levels. Mar. Biol. 157 (1), 29-47.

Lapointe, B.E., Bedford, B.J., 2010. Ecology and nutrition of invasive Caulerpa brachypus f. parvifolia blooms on coral reefs off southeast Florida, USA. Harmful Algae 9, 1-12.

Larned, S.T., 1998. Nitrogen-versus phosphorus-limited growth and sources of nutrients for coral reef macroalgae. Mar. Biol. 132, 409-421.

Liu, D.Y., Keesing, J.K., He, P.M., Wang, Z.L., Shi, Y.J., Wang, Y.J., 2013. The world's largest macroalgal bloom in the Yellow Sea, China: formation and implications. Estuar. Coast. Shelf Sci. 129, 2-10.

Macko, S.A., Ostrom, N.E., 1994. Pollution studies using stable isotopes. In: Lajtha, K., Michener, R.H. (Eds.), Stable Isotopes in Ecology and Environmental Science. Blackwell Scientific Publications, Oxford, UK, pp. 45-62.

McClelland, J.W., Valiela, I., 1998. Linking nitrogen in estuarine producers to land-derived sources. Limnol. Oceanogr. 43 (4), 577-585.

Nixon, S.W., 1995. Coastal marine eutrophication: a definition, social causes, and future concerns. Ophelia 41, 199-219.

Ochoa-Izaguirre, M.J., Soto-Jiménez, M.F., 2013. Evaluation of nitrogen sources in the Urías lagoon system, Gulf of California, based on stable isotopes in macroalgae. Cienc. Mar. 39 (4), 413-430.

Ochoa-Izaguirre, M.J., Soto-Jiménez, M.F., 2015. Variability in nitrogen stable isotope ratios of macroalgae: consequences for the identification of nitrogen sources. J. Phycol. 51, 46-65.
Pedersen, F.M., Borum, J., 1996. Nutrient control of algal growth in estuarine waters. Nutrient limitation and the importance of nitrogen requirements and nitrogen storage among phytoplankton and species of macroalgae. Mar. Ecol. Prog. Ser. 142, 261-272.

Piñón-Gimate, A., Serviere-Zaragoza, E., Ochoa-Izaguirre, M.J., Páez-Osuna, F., 2008. Species composition and seasonal changes in macroalgal blooms in lagoons along the southeastern Gulf of California. Bot. Mar. 51, 112-123.

Piñón-Gimate, A., Soto-Jiménez, M.F., Ochoa-Izaguirre, M.J., García-Pagés, E., Páez-Osuna F., 2009. Macrogalgae blooms and $\delta^{15} \mathrm{~N}$ in subtropical coastal lagoons from the southeastern Gulf of California: discrimination among agricultural, shrimp farm and sewage effluents. Mar. Pollut. Bull. 58, 1144-1151.

Raimonet, M., Guillou, G., Mornet, F., Richard, P., 2013. Macroalgae $\delta^{15} \mathrm{~N}$ values in wellmixed estuaries: indicator of anthropogenic nitrogen input or macroalgae metabolism? Estuar. Coast. Shelf Sci. 119, 126-138.

Raven, J.A., Taylor, R., 2003. Macroalgal growth in nutrient-enriched estuaries: biogeochemical and evolutionary perspective. Water Air Soil Poll. Focus 3, 6-7.

Rogers, K.M., 2003. Stable carbon and nitrogen isotope signatures indicate recovery of marine biota from sewage pollution at Moa Point, New Zealand. Mar. Pollut. Bull. $46,821-827$.

Savage, C., Elmgren, R., 2004. Macroalgal (Fucus vesiculosus) $\delta^{15} \mathrm{~N}$ values trace decrease in sewage influence. Ecol. Appl. 14, 517-526.

Schubert, P.R., Karez, R., Reusch, T.B.H., Dierking, J., 2013. Isotopic signatures of eelgrass (Zostera marina L.) as bioindicator of anthropogenic nutrient input in the western Baltic sea. Mar. Pollut. Bull. 72, 64-70.

Teichberg, M., Fox, S.E., Aguila, C., Olsen, Y.S., Valiela, I., 2008. Macroalgal responses to experimental nutrient enrichment in shallow coastal waters: growth, internal nutrient pools, and isotopic signatures. Mar. Ecol. Prog. Ser. 368, 117-126.

Teichberg, M., Fox, M.T., Olsen, Y.O., Valiela, I., Martinetto, P., Iribarne, O., Muto, E.Y., Petti, M.A.V., Corbisier, T.N., Soto-Jime'nez, M., Pa'ez-Osuna, F., Castro, P., Freitas, H., Zitelli, A., Cardinaletti, M., Tagliapietra, D., 2010. Eutrophication and macroalgal blooms in temperate and tropical coastal waters: nutrient enrichment experiments with Ulva spp. Chang. Biol. 16, 2624-2637.

Thornber, C.S., DiMilla, P., Nixon, S.W., McKinney, R.A., 2008. Natural and anthropogenic nitrogen uptake by bloom-forming macroalgae. Mar. Pollut. Bull. 56, 261-269.

Turpin, D.H., 1991. Effects of inorganic N availability on algal photosynthesis and carbon metabolism. J. Phycol. 27, 14-20.

Tyler, A.C., McGlathery, K.J., 2006. Uptake and release of nitrogen by the macroalgae Gracilaria vermiculophylla (rhodophyta). J. Phycol. 42, 515-525.

Tyler, A.C., McGlathery, K.J., Macko, S.A., 2005. Uptake of urea and amino acids by the macroalgae Ulva lactuca (chlorophyta) and Gracilaria vermiculophylla (rhodophyta). Mar. Ecol. Prog. Ser. 294, 161-172.

Umezawa, Y., Miyahima, T., Yamamuro, M., Kayanne, H., Koike, I., 2002. Fine scale mapping of land derived nitrogen in coral reefs by $\delta 15 \mathrm{~N}$ in macroalgae. Limnol. Oceanogr 47, 1405-1416.

Umezawa, Y., Miyajima, T., Tanaka, Y., Koike, I., 2007. Variation in internal d15N and d13C distributions and their bulk values in the brown macroalga Padina australis growing in subtropical oligotrophic waters. J. Phycol. 43, 437-448.

Viana, I.G., Bode, A., 2013. Stable nitrogen isotopes in coastal macroalgae: geographic and anthropogenic variability. Sci. Total Environ. 443, 887-895.

Viana, I.G., Bode, A., 2015. Variability in $\delta^{15} \mathrm{~N}$ of intertidal brown algae along a salinity gradient: differential impact of nitrogen sources. Sci. Total Environ. 512-513, 167-176.

Vitòria, L., Otro, N., Soler, A., Canals, À., 2004. Fertilizer characterization: isotopic data (N, S, O, C, and Sr). Environ. Sci. Technol. 38, 3254-3262.

Wang, Y.J., Liu, D.Y., Dong, Z.J., Di, B.P., Shen, X.H., 2012. Temporal and spatial distributions of nutrients under the influence of human activities in Sishili Bay, northern Yellow Sea of China. Mar. Pollut. Bull. 64, 2708-2719.

Zhang, D.H., Wang, H., 2010. Determination of the parameters for the discharging tube from Taoziwan waste water treatment plant in Yantai. Coastal Engineering 29 (1) 46-52 (2010, in Chinese with English abstract).

Zhao, W., Jiao, N., Zhao, Z., 2000. Forms of nitrogen in the Yantai Sishili Bay cultivated water. Oceanologia et Limnologia Sinica 31, 53-59 (in Chinese, with English abstracts).

Zhou, Y., 2000. Foundational studies on effects of raft culture of filterfeeding bivalves on coastal ecological environment (PhD Thesis), Institute of Oceanology, Chinese Academy of Sciences (in Chinese).

Zhou, Y., Yang, H.S., Zhang, T., Qin, P.B., Xu, X.L., Zhang, F.S., 2006. Density-dependent effects on seston dynamics and rates of filtering and biodeposition of the suspensioncultured scallop Chlamys farreri in a eutrophic bay (northern China): an experimental study in semi-in situ flow-through systems. J. Mar. Syst. 59, 143-158.

Zhuang, S.H., Chen, L.X., 2003. Seasonal fluctuation of benthic algal community in the rocky intertidals of Moon Bay, Yantai. J. Ocean Univ. Qingdao 33 (5), 719-726 (in Chinese with English abstract).

Zhuang, S.H., Chen, L.X., Wang, K.M., 2010. The spatial distribution pattern of benthic Rhodophyta in Yantai lithofacies intertidal zones of Yellow Sea. J. Yantai Univ. (Nat. Sci. Eng. Ed.) 14 (4), 255-265 (in Chinese with English abstract). 